\title{
The curse of being serpentiform: Perceptions of snakelike animals in São Paulo, Brazil
}

\author{
Jade Lima-Santos ${ }^{1 *} ;$ Henrique Caldeira Costa $^{2}$ and Flavio de Barros Molina ${ }^{3}$
}

\begin{abstract}
Serpentiform body is a morphological adaptation present in several groups of animals. This body shape is often associated with snakes, which can result in the indiscriminate killing of animals. Despite their great socioeconomic and ecological importance, snakes are commonly associated with feelings of aversion, fear, and disgust, that may lead to the inhibition of conservation measures. The present work was conducted in the vicinity of the M'Boi Mirim Park, in São Paulo (Brazil) to record popular knowledge and to discuss public feelings and attitudes towards snakes and other elongated legless animals. We conducted semistructured interviews with 70 participants. The largest percentage of the participants identified snakes by the forked tongue and cylindrical body shape, obvious characteristics to human eyes. In an encounter with a serpentiform animal that may be a venomous snake, this behavior is advantageous as it is better to deal with a false positive than with a false negative. However, this result demonstrated a lack of adequate knowledge about the morphological traits exclusive to snakes. Many participants are afraid of snakes, which, along with misidentification, can cause disastrous encounters and lead to the killing of any snakelike animal. Furthermore, we found that even in a large city, legends and myths about snakes and snakelike animals are passed on through generations. Additionally, people are unaware that some snake populations or even species are under risk of extinction. Our results point to the need for an educational program that changes public attitudes towards snakes and snakelike animals at Municipal parks.
\end{abstract}

Keywords: Ethnoherpetology; Ethnozoology; Snakes; Popular knowledge; Conservation.

1 Programa de Pós-Graduação em Ecologia e Evolução, Universidade Federal de São Paulo, Campus Diadema, Rua Artur Riedel, 275, Bairro Eldorado, Diadema, SP, Brazil.

2 Universidade Federal de Juiz de Fora, Departamento de Zoologia, Campus Universitário, 36036-900. Juiz de Fora, MG, Brazil

3 Universidade de Santo Amaro, Campus I, Rua Professor Enéas de Siqueira Neto 340, Jardim das Imbuias, São Paulo, SP, Brazil $^{*}$

*Corresponding author. \E-mail address: JLS (jadelima26@gmail.com), HCC (ccostah@gmail.com), FBM (fbmolina@uol.com.br) 


\section{SIGNIFICANCE STATEMENT}

As a protective measure, the number of urban parks in Atlantic Forest has grown in the last decades. It is important to know the socioeconomic profile and popular knowledge of the residents who attend the parks in order to minimize possible negative impacts on the area. Our data show that even in megalopolis like São Paulo people are afraid of snakes and oral tradition is relevant in myths and legends transmission about these animals. Unfortunately, most legends evoke evil snakes, which can hinder conservation efforts. As already pointed out by many researchers, educational activities involving both children and adults are especially important to guarantee faunal conservation in the presence of feared animals; the same is true for snakes. With the skilled transfer of knowledge, it may be possible to improve positively the image public have about unfamiliar or misunderstood animals and to work with people's ecocentrism to enhance species conservation.

\section{INTRODUCTION}

Snakes evolved from a group of limbed vertebrates around 170 million years ago (Scanlon and Lee 2011; Caldwell et al. 2015) and early in their evolutionary history they lost their limbs and underwent body elongation by significantly increasing the number of vertebrae (Wiens and Slingluff 2001; Caldwell 2003; Brandley et al. 2008; Burbrink and Crother 2011). A serpentiform body seems to be very adaptive since it evolved independently at least 26 times in the Squamata clade (Wiens et al. 2006), as well as in caecilians (Gymnophiona), salamanders (Caudata) (Caldwell 2003; Wilkinson et al. 2011) and many invertebrate groups, such as oligochaetes (Drumond et al. 2013).

The serpentiform body triggers instinctive defensive responses in primates, which quickly detect and become alert in the presence of snakes (Shibasaki and Kawai 2009; Kawai and Koda 2016; Falótico et al. 2018). This predator-prey relationship seems to be so intense that Isbell (2006) proposed the hypothesis that primates perceive snakes faster than they perceive inoffensive stimuli. According to the snake detection hypothesis (SDH), the imminence of a strike can be predicted from the snake posture.
Accordingly, recent studies support the SDH (e.g. Öhman et al. 2012; Soares et al. 2014; Gomes et al. 2017; Isbell and Etting 2017).

In humans, even preschool children are capable of rapid snake detection (Lobue and Deloache 2008, 2011; Penkunas and Coss 2013; Thrasher and Lobue 2016). The visual system and related neuronal modules probably evolved, at least partially, as a response to an arms race between snakes and primates (Isbell 2006; Öhman et al. 2012; Penkunas and Coss 2013; Kawai and He 2016; Gomes et al. 2017). After millions of years of coevolution, potentially deadly snakes seem to represent an archetypal human phobia that automatically activates a brain fear module (Öhman and Mineka 2003; Öhman et al. 2012; Prokop 2016; Gomes et al. 2017). It is likely that the human demographic and geographic expansion also facilitated the rapid transmission of knowledge about snakes' dangerousness (Alves and Albuquerque 2018).

Due to this evolutionary history of fear and avoidance, humans not only are attentive to the presence of snakes, but usually also try to kill them whenever the opportunity arises (Santos-Fita et al. 2010; Alves et al. 2012a, 2012b; Mendonça et al. 2014; Nonga and Haruna 2015; Pandey et al. 2016). Furthermore, this widespread fear 
of snakes can lead to a fear of any animal that has a snakelike form. For this reason, being serpentiform may be a 'curse' and may result in harmless species, such as amphisbaenians or glass lizards, suffering the same snake-directed rage (Alves et al. 2012a, 2012b). Such fear of snakes and animals with snakelike forms have serious implications for conservation efforts, with these daily experiences becoming a reservoir of so-called local ecological knowledge (LEK, see Alves and Lopes 2018) that may be transmitted across generations. Myths, beliefs and legends across the world (from Americas to New Guinea, from Greek to Japanese mythologies) usually show snakes evoking fear, disgust, fascination and curiosity (Vizotto 2003). Such stories became well established through time and were reinforced by being continuously transmitted to new audiences (Corso and Corso 2006) resulting in a spread of fear and negative perception of snakes (Burghardt et al. 2009).

The knowledge of how humans interact with snakes and what local ecological knowledge is shown by people is of key importance to the establishment of educational programmes and conservation strategies (Alves and Lopes 2018). In the city of São Paulo, southeastern Brazil, the difficulty in implementing adequate policies related to human occupation and the high rate of population growth and migration has caused recurrent conflicts over space and consequent widespread pollution and deforestation. Today, $30 \%$ of São Paulo population (equivalent to over five million people) puts an incredible pressure on the last Atlantic Forest remnants located on north and south border of the municipality (Mello-Thery 2011). Considering that part of these areas is protected and include water springs, such as M'Boi Mirim Park, the encounter between people and snakes or other serpentiform animals is not rare. Using an ethnoherpetological approach, we aimed to investigate the perception of people living near this park towards snakes and snakelike animals, and how they interact with them. We hypothesized that the fear of snakelike animals will be widespread among participants.

\section{MATERIAL AND METHODS}

M'Boi Mirim Municipal Park $\left(23^{\circ} 42^{\prime} 24^{\prime \prime} \mathrm{S}\right.$, $46^{\circ} 47^{\prime} 04^{\prime \prime} \mathrm{W}$ (in the native language Tupi, mboîa means 'snake' and mirim means 'small'), was selected due to its location on São Paulo's south border, where there are many patches of green areas (Raimundo 2006), although surrounded by illegal buildings. We interviewed 70 inhabitants of the region, with an equal number of males and females, near the main entrance of the M'Boi Mirim Municipal Park. We collected the data using semistructured interviews with open and closed-ended questions, allowing higher interaction with the participants and, consequently, better access to their knowledge and beliefs (Albuquerque et al. 2014b). We randomly selected and stratified participants according to gender (Albuquerque et al. 2014a). Only one researcher (JLS) conducted the interviews between July and August 2014 following the method proposed by Albuquerque et al. (2014b) to avoid researcher bias. This research followed the guidelines of the Declaration of Helsinki and Tokyo for humans and was approved by the Ethics Committee of the Santo Amaro University/UNISA (Process 871286, dated November 13, 2014).

The questionnaire included 16 questions (Q.) designed to provide some understanding of the participants' (i) 
previous experiences with snakes (Q1-3), snakes and other serpentiform animals (ii) knowledge about the morphology of (Q4-7), (iii) feelings and attitudes towards

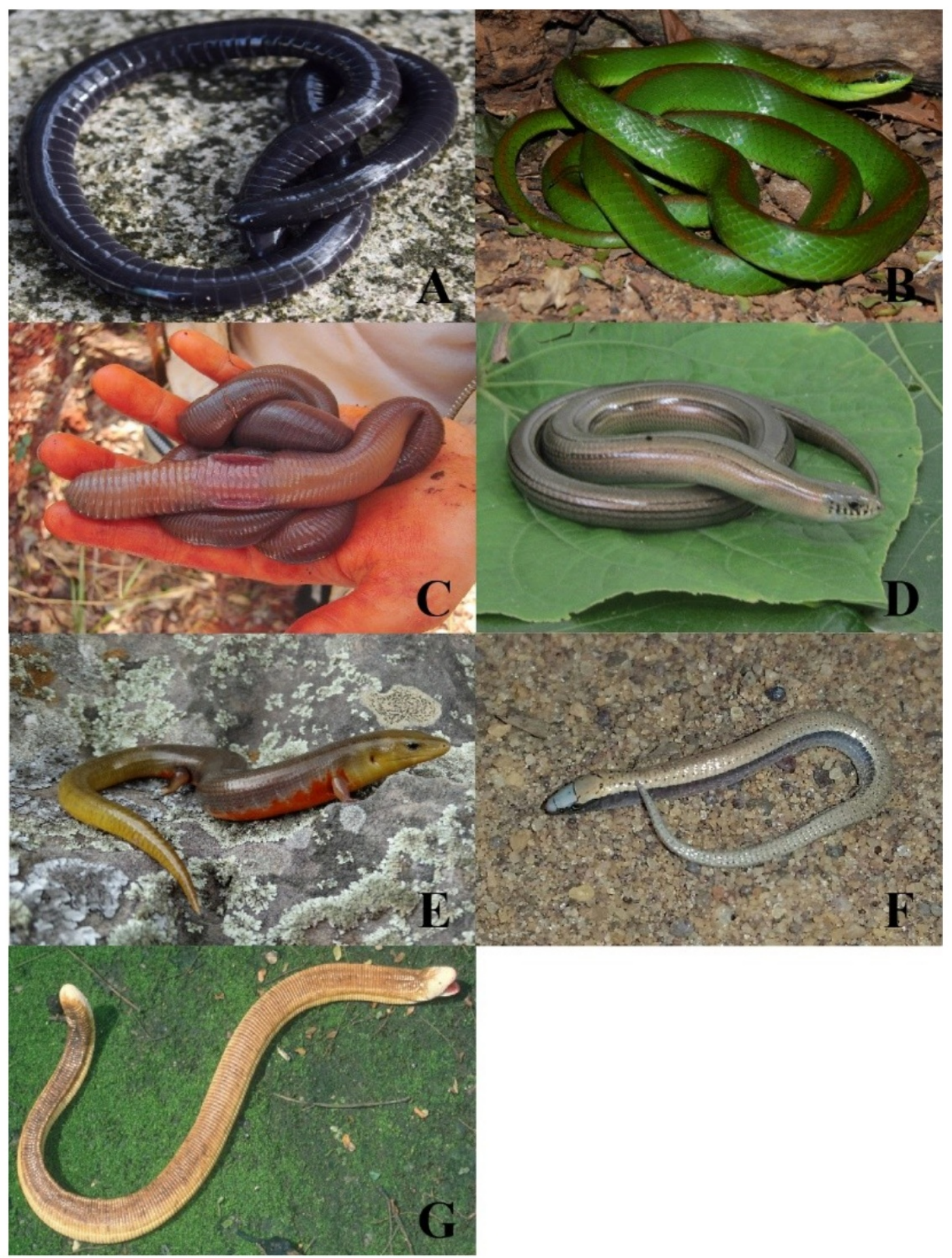

Figure 1. Coloured photographs presented to the interviewed in a randomly defined order. A) Ringed caecilian (Siphonops annulatus). B) South American green racer (Philodryas olfersii). C) Giant earthworm (Rhinodrillus alatus). D) Striped glass-lizard (Ophiodes striatus). E) Brazilian galliwasp (Diploglossus lessonae). F) Catimbau sand slider (Scriptosaura catimbau). G) Giant worm lizard (Amphisbaena alba). Photos by Marcelo Duarte (A, B, G), Projeto Minhocuçu, UFMG (C), Jade LimaSantos (D), and Marco Antonio de Freitas (E, F). 
snakes (Q8-11), (iv) knowledge about the importance of snakes (Q12-15), (v) and knowledge about snake myths and legends (Q16) (Supplementary Materials: Questionnaire).

We elaborated Question 7 to be asked in association with unlabelled pictures of seven serpentiform animals, used as a visual stimulus (Alves et al. 2014) to determine if the participants would classify these animals as "true snake" or "not a true snake" (Figure 1). We also asked which criteria participants used to justify their classification. We were especially interested in quantifying the proportion of participants that would consider other serpentiform animals, like legless lizards and the giant earthworm, as a true snake. We included the Brazilian galliwasp (Diploglossus lessonae), a legged lizard, because for many people even lizards with small limbs can be mistaken for a snake (Shine and Koenig 2001). Finally, we evaluated the correlation between age and education with fear intensity expressed by participants, using models of one factor analysis of variance (ANOVA).

\section{RESULTS}

We interviewed participants between 18 and 67 years old, all residents of the region in the vicinity of the M'Boi Mirim Park (Q. Table 1. Morphological characters useful to identify a snake according to 35 men and 35 women interviewed at the M'Boi Mirim Municipal Park, São Paulo, Brazil, between July and August 2014.

\begin{tabular}{lll}
\hline Morphological characters & \multicolumn{1}{c}{$\mathbf{O}^{\mathbf{T}}$} & \multicolumn{1}{c}{$\mathbf{q}$} \\
\hline Forked tongue & $54.3 \%(n=19)$ & $62.9 \%(n=22)$ \\
Cylindrical body shape & $45.7 \%(n=16)$ & $28.6 \%(n=10)$ \\
Scales & $20.0 \%(n=7)$ & $25.7 \%(n=9)$ \\
Absence of legs & $14.3 \%(n=5)$ & $17.1 \%(n=6)$ \\
Rattle & $14.3 \%(n=5)$ & $11.4 \%(n=4)$ \\
Colour & $11.4 \%(n=4)$ & $8.6 \%(n=3)$ \\
Head shape & $5.7 \%(n=2)$ & $17.1 \%(n=6)$ \\
\hline
\end{tabular}

$01)$. Most participants $(100 \%$ of men and $97.1 \%$ of women) had seen a snake before, especially through the media (Q. 02). Also, encounters with snakes in the M'Boi Mirim area were not rare $(57.1 \%[n=20]$ of men and $60 \%$ [n=21] of women, Q. 03). We then asked participants to point out which were typical snake characters (Q. 04). In sequence, we showed a list with three snake and three non-snake characters (Q. 05). On both questions, there was agreement regarding the morphological characters that most attracted people's attention (Table 1).

More women $(48.6 \%, \mathrm{n}=17)$ than men $(22.9 \%, n=8)$ knew legless animals that are not snakes (Q. 06). The most cited species was the marbled swamp eel (Synbranchus marmoratus), a Pan-American eel-like fish with reduced fins and scales. Most men and women also misclassified five of the seven long-bodied animals we showed at photographs as a true snake (Q. 07, Table 2). Altogether, over $75 \%$ participants misidentified four snakelike animals as snakes, with Amphisbaena alba the most misidentified species.

Though $51.4 \%$ of men and $77.1 \%$ of women feel themselves uneasy regarding snakes (Q. 09), most men $(94.3 \%, n=33)$ and women $(74.3 \%, \quad n=26)$ considered snakes dangerous (Q. 10). They based their judgement on the ability of these animals to inject venom. Despite that, only $37.1 \%$ $(n=13)$ of men and $62.9 \%(n=22)$ of women answered 'yes' when directly asked if they feared snakes ( $Q$. 11). Judging by the proportion of men and women that marked 4 or 5 on the scale of fear intensity (from 0 [no fear] to 5 [extreme fear]), the real proportion of men and women that are afraid of snakes increased to $68.6 \% \quad(n=24)$ of men and $88.6 \%(n=31)$ of women (Table 3). According to the scale of fear intensity, men seem to be less afraid than women since most men 
Table 2. Classification of serpentiform animals in the categories defined as "a true snake" and "not a true snake" by 35 men and 35 women interviewed at the M'Boi Mirim Municipal Park, São Paulo, Brazil, between July and August 2014.

\begin{tabular}{|c|c|c|c|c|}
\hline \multirow[b]{2}{*}{ Species } & \multirow{2}{*}{ 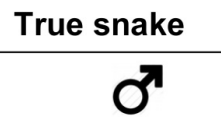 } & & \multicolumn{2}{|c|}{ Not a true snake } \\
\hline & & 9 & б & 9 \\
\hline $\begin{array}{l}\text { South American green racer } \\
P . \text { olfersii }\end{array}$ & $100 \%(n=35)$ & $97.1 \%(n=34)$ & $0 \%(n=0)$ & $2.9 \%(n=1)$ \\
\hline $\begin{array}{l}\text { Giant worm lizard } \\
\text { A. alba }\end{array}$ & $91.4 \%(n=32)$ & $94.3 \%(n=33)$ & $8.6 \%(n=3)$ & $5.7 \%(n=2)$ \\
\hline $\begin{array}{l}\text { Striped glass-lizard } \\
\text { O. striatus }\end{array}$ & $88.0 \%(n=31)$ & $94.3 \%(n=33)$ & $12.0 \%(n=4)$ & $5.7 \%(n=2)$ \\
\hline $\begin{array}{l}\text { Catimbau sand slider } \\
\text { S. catimbau }\end{array}$ & $80.0 \%(n=28)$ & $91.4 \%(n=32)$ & $20.0 \%(n=7)$ & $9.6 \%(n=3)$ \\
\hline $\begin{array}{l}\text { Ringed caecilian } \\
\text { S. annulatus }\end{array}$ & $77.1 \%(n=27)$ & $82.9 \%(n=29)$ & $22.9 \%(n=8)$ & $17.1 \%(n=6)$ \\
\hline $\begin{array}{l}\text { Giant earthworm } \\
R \text {. alatus }\end{array}$ & $37.1 \%(n=13)$ & $48.6 \%(n=17)$ & $62.9 \%(n=22)$ & $51.4 \%(n=18)$ \\
\hline $\begin{array}{l}\text { Brazilian galliwasp } \\
\text { D. lessonae }\end{array}$ & $100 \%(n=35)$ & $97.1 \%(n=34)$ & $0 \%(n=0)$ & $2.9 \%(n=1)$ \\
\hline
\end{tabular}

Table 3. Comparison between ranks selected by the participants (35 men and 35 women) in relation to the fear elicited by snakes. Zero means no fear while five represents extreme fear.

\begin{tabular}{lll}
\hline Ranks & \multicolumn{1}{c}{$\mathbf{O}^{7}$} & \multicolumn{1}{c}{$\mathbf{q}$} \\
\hline 0 & $31.4 \%(n=11)$ & $11.4 \%(n=4)$ \\
1 & $11.4 \%(n=4)$ & $14.3 \%(n=5)$ \\
2 & $14.3 \%(n=5)$ & $14.3 \%(n=5)$ \\
3 & $11.4 \%(n=4)$ & $11.4 \%(n=4)$ \\
4 & $11.4 \%(n=4)$ & $17.2 \%(n=6)$ \\
5 & $20.1 \%(n=7)$ & $31.4 \%(n=11)$ \\
Total & $100 \%$ & $100 \%$ \\
\hline
\end{tabular}

(42.8\%, $\mathrm{n}=15)$ marked 0-1 while most women $(48.6 \%, n=17)$ marked $4-5$ regarding their fear intensity of snakes. Education level $(F(1,5)=0.84, \quad p=0.52)$ and age $(F(1,68)=$ $0.08, p=0.78$ ) were not correlated with fear expressed by participants.

Women appear to be more fearful of snakes; most men $(80 \%, \mathrm{n}=28)$ but not women $(54.3 \%, n=19)$ said they would continue visiting M'Boi Mirim Park even if they observed a snake in the walking trail (Q. 08). When asked what they would do if encountering a snake (Q. 14), more than half of the participants $(54.3 \%$ of men and $57.1 \%$ of women) said they would not disturb the animal. However, $11.4 \%$ of men and $22.9 \%$ of women said they would run away and $17.1 \%$ of men and women answered they would kill the snake.

Snakes were considered important animals for the environment (Q. 12) by most men $(74.3 \%, n=26)$ and women $(88.6 \%$, $\mathrm{n}=31$ ). They based their judgement on the ecological role of these animals, especially as predators of pest animals. Importance to the economy (Q. 15) was stressed by most men $(65.7 \%, n=23)$ and women $(60 \%$, $n=21)$. Men justified their opinion based on the production of snake antivenin $(n=11)$, the manufacture of leather products $(n=5)$, the development of the snake charming industry $(n=1)$ and the breeding for the pet trade $(n=1)$. Women added the importance snakes have to the bio-pharmacological industry, 
Table 4. Comparative cognition table with participant's knowledge of legends and myths, with sex and age of participants.

\begin{tabular}{|c|c|c|}
\hline Participant's knowledge & Sex & Age \\
\hline "There is a giant snake of the Amazon" & Woman & 33 \\
\hline "We were banned from Paradise because of the snake." & Woman & 36 \\
\hline $\begin{array}{l}\text { "The snake was a quadruped animal but when it gave the apple to Eve, God } \\
\text { became furious and punished it by transforming it in a reptile." }\end{array}$ & Man & 46 \\
\hline $\begin{array}{l}\text { "The black snake puts its tail in the mouth of a child and sucks milk from the } \\
\text { mother." }\end{array}$ & Woman & 50 \\
\hline $\begin{array}{l}\text { "Putting a snake inside the cachaça bottle [Brazilian alcohol drinking] gives man } \\
\text { sexual strength." }\end{array}$ & $\begin{array}{l}\text { Man } \\
\text { Man }\end{array}$ & $\begin{array}{l}59 \\
60\end{array}$ \\
\hline "The anaconda is a water snake, a smart animal that eats a bull." & Man & 36 \\
\hline $\begin{array}{l}\text { "If you do not kill a snake that crosses your path it will follow you and bites you." } \\
\text { "A snake curls around sleeping people to kill them." } \\
\text { "The anaconda is an animal that stays hidden in the bottom of a river waiting to kill } \\
\text { a passerby." }\end{array}$ & $\begin{array}{l}\text { Man } \\
\text { Man } \\
\text { Man } \\
\text { Man }\end{array}$ & $\begin{array}{l}35 \\
18 \\
29 \\
61\end{array}$ \\
\hline
\end{tabular}

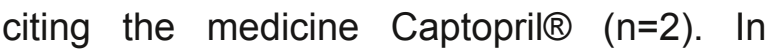
general, participants were not aware of the problems faced by snake populations $(\mathrm{Q}$. $14)$, with $62.9 \%(n=22)$ of men and $77.1 \%$ $(n=27)$ of women not knowing any species at risk of extinction. Many participants showed a great knowledge about myths and legends involving snakes (Q. 16; Table 4).

\section{DISCUSSION}

This study is the first to record popular knowledge about snakes and other snakelike animals, and to discuss peoples' feelings and attitudes towards these serpentiform creatures in an urban area of São Paulo municipality. It is important to know the socioeconomic profile and popular knowledge of the residents who visit the park to minimize possible negative impacts on the area. Similar research was conducted in other areas of Brazil, especially in the states of Paraíba (Barbosa et al. 2007; Alves et al. 2014; Mendonça et al. 2014; Araujo and Luna 2017; Pontes et al. 2017), Ceará (Fernandes-Ferreira et al. 2012; Pinheiro et al. 2016), Bahia (Marques and Guerreiro 2007; Baptista et al. 2008; Santos-Fita et al.
2010) and Minas Gerais (Mateus et al. 2011; Moura et al. 2010; Pinto et al. 2012; Dias et al. 2018; Lima et al. 2018).

Since an encounter with a venomous snake can be lethal (1546 bothropic accidents in the state of São Paulo between 1959 and 2011 [Galvão 2011]), there is often a low threshold regarding whether an elongated object is or is not a snake (Wilke and Mata 2012). Although most participants had previously seen a live snake, a few rapidly perceived traits, such as a long and slender shape, can be enough to cause an observer to decide that an observed object is a snake. Mistakes will occur in the identification of a recurrent danger in the wild, but as stressed by Wilke and Mata (2012) it is better to deal with a false positive ("oh man, it is just a twig...") than with a false negative ("oh God, I was bitten!"). This explains why the largest percentage of participants in this study highlighted the presence of easily recognized traits such as a forked tongue and the cylindrical body shape. These traits, besides being easy to observe, are commonly used in the description of the snake body shape in lessons and videos. A smaller group 


\section{Ethnobiology and Conservation}

highlighted other obvious traits, like the absence of legs and the presence of bodycovering scales. Traits that are hard to see, such as head shape and tooth details, were rarely mentioned.

Although the rapid detection of easily observed snake traits protected humans from disastrous encounters with snakes, it also exposes harmless snakes and other serpentiform animals to indiscriminate killing. Consistent characters that allow an accurate identification of a serpentiform animal as not a snake are inconspicuous and difficult to check in the few seconds available to make a decision (Shine 1991). The similarity of snakes to other animals and the archetypal human's ophidiophobia (Fredrikson et al. 1996; Polák et al. 2016) may account for the curse of being serpentiform. This may explain why even the striped glass lizard (Ophiodes striatus), the Catimbau sand slider (Scriptosaura catimbau) and the ringed caecilian (Siphonops annulatus) were identified as snakes by more than $75 \%$ of the participants. Details such as the movable eyelids of $O$. striatus, the rudimentary hind limbs of $S$. catimbau and the ring-shaped body folds of $S$. annulatus (all absent in snakes) are not traits that one can rapidly observe. Curiously, the Brazilian galliwasp (Diploglossus lessonae), a four-legged (although having short limbs) and relatively elongate lizard was identified by almost all participants as being a true snake. When threatened, Diploglossus spp. usually adpress the limbs against the body and flee with snakelike movements (Marques et al. 2019). Together with the fact that fewer than $15 \%$ of men and $17 \%$ women cited the absence of limbs as a character of true snakes, this reinforces the 'curse' of serpentiform body shape.

Subtle characters present in non-ophidian serpentiform animals are difficult to check immediately and can be erroneously attributed to snakes. About $28 \%$ of the participants stated that snakes have movable eyelids and external ears. This may explain why, when asked to spontaneously name legless elongate animals other than snakes, the largest percentage named a fish (Synbranchus marmoratus, locally known as 'muçum') and not a Squamata nor a Gymnophiona. Erroneous identification of other legless elongate animals as snakes seems to be common. Caecilians, amphisbaenians and some lizards are usually considered snakes in Brazil by lay people (Baptista et al. 2008; Mateus et al. 2011; Fernandes-Ferreira et al. 2012; Pinto et al. 2012; Alves et al. 2014; Lima et al. 2018), a kind of misidentification also observed in other countries (e.g. Shine 1991 Whitaker and Shine 2000; Shine and Koenig 2001; Lillywhite 2014).

Snakes usually evoke feelings of danger and fear in both adults and children. These emotions seem to be reinforced by the controversial way in which social media portrays these animals (Cosendey and Salomão 2016). In a study conducted by Nolan et al. (2006), snakes ranked second in a list of disliked animals by American college students. The same attitude was observed in Brazil (e.g. Santos-Fita et al. 2010; Alves et al. 2014; Mendonça et al. 2014; Lima et al. 2018; Vasconcelos-Neto et al. 2018) and elsewhere (e.g. Shine 1991; Whitaker and Shine 2000; Prokop et al. 2009; Nonga and Haruna 2015; Pandey et al. 2016; GarcíaLópez et al. 2017; Gros-Désormeaux et al. 2017; Landová et al. 2018).

Men may be less afraid of snakes than women, as suggested by the scale of fear intensity, which may be related to a more effective way they have to deal with aversive situations by applying a problem-focused strategy and not the emotional-focused 
strategy usually applied by women (Mclean and Anderson 2009). In this study, the number of women who said they would run away in a supposed encounter with a snake was twice the number for men.

Despite hate and fear directed towards snakes, some participants seemed to understand the environmental importance of these reptiles, especially considering their position on the trophic web as predators that control pests such as rodents and other snakes. This same perception was observed elsewhere (Costa-Neto 2000; Santos-Fita 2010; Alves et al. 2014; Lima et al. 2018). Unfortunately, the ecological problems faced by snake populations seem to be unknown to most people and therefore they are unaware of the necessity of conservation efforts (Pandey et al. 2016).

The economic importance of snakes seemed less obvious than their environmental relevance. Among the participants that knew about economic topics, only women mentioned the importance to the bio-pharmacological industry. Similar results were published by Alves et al. (2014) and Lima et al. (2018). Contrary to frequent statements by people living in rural areas (e.g. Costa-Neto 2000; Santos-Fita et al. 2010; Alves et al. 2012; Pandey et al. 2016), our participants did not mention the use of snakes as a source of protein and for preparing traditional medicines.

When asked about myths and legends, participants gave a varied number of examples. Oral tradition is responsible for the transmission of legends, which makes the emergence of erroneous stories common. As expected, a reasonable number cited the Biblical myth of Adam and Eve. However, the most cited was the legend of the Amazonian giant snake (anaconda or sucuri), commonly heard in Brazil (Murphy and Henderson 1997). The legend of snakes that breastfeed on women, or nurse on cows, was reported by some participants and seems to be widespread (Casas-Andreu 2000; Santos-Fita et al. 2010; FernandesFerreira et al. 2012; Achille 2015; Pandey et al. 2016; Gros-Désormeaux et al. 2017; Pontes et al. 2017;). The legend of vengeful snakes that pursue people is also common in other parts of Brazil (Vizotto 2003; Santos-Fita et al. 2010; Fernandes-Ferreira et al. 2011), and in other countries (Klauber 1972; Mitchell 1982; Casas-Andreu 2000; Achille 2015). A possible explanation for this is the aggressiveness of certain species, and the panic of the supposedly persecuted person (Mitchell 1982; Whitaker and Shine 2000; Vizotto 2003).

Men also reported the aphrodisiac power of distilled alcoholic drinks made from sugar cane ("cachaça") and bottled with a snake, known in Brazil as "pinga de serpente". These alcoholic drinks are sometimes prescribed to prevent snakebite (Costa-Neto 2000; Santos-Fita 2010). In Italy, the equivalent beverage is wine bottled with vipers and it is prescribed to cure scurvy (Achille 2015). In the USA, whiskey is bottled with rattlesnakes and used to treat rheumatism (Klauber 1972). In East and Southeast Asia, the snake wine industry is very prominent. The beverage is supposed to cure many different conditions, like hair loss, rheumatism and lumbago, and to improve sexual performance (Somaweera and Somaweera 2010).

In an influential review of the history and development of ethnozoology in Brazil, Alves and Souto (2011) highlighted the importance of faunal and cultural diversity as a scenery to understand human-nonhuman animal relationships. As they stressed, ethnozoological studies are of key importance to evaluating anthropic impacts 
on native fauna and to implementing sustainable management plans. The city of São Paulo, with its population density of almost 7,400 people $/ \mathrm{km}^{2}$ and important remnants of Atlantic Forest, presents an interesting scenario in the development of ethnobiological studies (IBGE 2019). Population growth rate of $0.55 \%$ per year (SEADE 2019) is a constant pressure that drives illegal deforestation. The balance between the need to expand settlement areas and the urge to preserve the forest remnants is very delicate (Mello-Théry 2011).

\section{CONCLUSIONS}

We have shown that even in a megalopolis like São Paulo, people are afraid of snakes and oral tradition is relevant in transmission of myths and legends about these animals. Unfortunately, most legends evoke evil snakes, which can hinder conservation efforts. As already pointed out by many researchers, educational activities involving both children and adults are especially important to guarantee faunal conservation in the presence of feared animals, including snakes. With the skilled transfer of knowledge, it may be possible to improve positively the image the public have about unfamiliar or misunderstood animals and to work with people's ecocentrism to enhance species conservation. An educational programme that changes feelings and attitudes towards serpentiform animals, and towards nature in general, should be designed and implemented at the M'Boi Mirim Municipal Park. Emphasis on ecosystem services provided by snakes, such as pest control and energy flow in trophic webs, is of key importance.

\section{ACKNOWLEDGEMENTS}

We are thankful to Camila Ingrid Marques Almeida, Pedro de Campos Mello Monteiro and Stefane Saruhashi and four anonymous reviewers for suggestions made on earlier versions. We thank Ross MacCulloch for the English review. Dodora Drumond, Marcelo Ribeiro Duarte, Marco Antonio de Freitas for the photos used at work. Carel P. Van Schaik, Eckhard W. Heymann, José María Gutiérrez, Lynne A. Isbell, Marco Antonio Ribeiro Júnior, Michael Penkunas, Nancy Caine, Nuno Gomes, Richard Shine, Uirá Souto Melo, Vanessa LoBue and Vivek Philip Cyriac kindly helped with bibliography acquisition.

\section{DATA AVAILABILITY}

The data used to support the findings of this study are available from the corresponding author upon reasonable request.

\section{CONFLICTS OF INTEREST}

The authors have no conflicts of interest to declare.

\section{CONTRIBUTION STATEMENT}

Conceived of the presented idea: JLS, FBM

Carried out the interviews: JLS

Carried out the data analysis: JLS, HCC

Wrote the first draft of the manuscript: JLSÐ

Review and final write of the manuscript: JLS, HCC, FBM

Supervision: FBM. 


\section{REFERENCES}

Achille G (2015) Myths and Legends About Italian Snakes. In: Achille G, Andreone F, Caputla M, Maugeri S, Pedrotti F, Zuffi MAL (eds) Snakes of Italy: Herpetological Treatise on the Biology and Iconography of Italian Ophidians. Springer Briefs In Animal Sciences, New York, pp. 173-402.

Albuquerque UP, Lucena RFP, Neto EMDFL (2014a) Selection of research participants. In: Albuquerque UP, Cunha LVFC, Lucena RFP, Alves RRN (eds) Methods and techniques in ethnobiology and ethnoecology. Humana Press, New York, pp. 1-13.

Albuquerque UP, Ramos MA, Lucena RFP, Alencar NL (2014b) Methods and Techniques Used to Collect Ethnobiological Data. In: Albuquerque UP, Cunha LVFC, Lucena RFP, Alves RRN (eds) Methods and techniques in ethnobiology and ethnoecology. Humana Press, New York, pp. 15-37.

Alves RRN, Souto WM (2011) Ethnozoology in Brazil: current status and perspectives. Journal of ethnobiology and ethnomedicine 7, 22. https://doi.org/10.1186/1746-4269-7-22.

Alves RRN, Pereira-Filho GA, Vieira KS, Souto WMS, Mendonça LET, Montenegro PFGP, Almeida WO, Vieira WLS (2012a) A zoological catalogue of hunted reptiles in the semiarid region of Brazil. Journal of ethnobiology and ethnomedicine doi:10.1186/1746-4269-8-27.

Alves RRN, Vieira KS, Santana GG, Vieira WLS, Almeida WO, Souto WMS, Montenegro PFGP, Pezzuti JCB (2012b) A review on human attitudes towards reptiles in Brazil. Environmental Monitoring and Assessment 184(11): 6877-6901.

Alves RRN, Silva VN, Trovão DM, Oliveira JV, Mourão JS, Dias TL, Alves AGC, Lucena RFP, Barboza RRD, Montenegro PFGP, Vieira WLS, Souto WMS (2014) Students' attitudes toward and knowledge about snakes in the semiarid region of Northeastern Brazil. Journal of ethnobiology and ethnomedicine http://dx.doi.org/10.1186/1746-4269-10-30.

Alves RRN, Albuquerque UP (2018) Introduction: animals in our lives. In Ethnozoology. Academic Press, pp. 1-7. Alves RRN, Faria Lopes S (2018) The Role of Ethnozoology in Animal Studies. In: Alves RRN, Albuquerque UP (eds) Ethnozoology: Animals in our Lives. Humana Press, London, pp. 467-479.
Araujo DFS, Luna KPO (2017) Os Répteis e sua Representação social: uma Abordagem Etnozoologica. Ethnoscientia 2(1).

Baptista GCS, Costa-Neto EM, Valverde MCC (2008) Diálogo entre concepções prévias dos estudantes e conhecimento científico escolar: relações sobre os Amphisbaenia. Revista Iberoamericana de Educación 47(2): 116.

Barbosa AR, Nishida AK, Costa ES, Cazé ALR (2007) Abordagem etnoherpetológica de São José da Mata-Paraíba-Brasil. Revista de Biologia e Ciências da Terra 7(2).

Brandley MC, Huelsenbeck JP, Wiens JJ (2008) Rates and patterns in the evolution of snake like body form in squamate reptiles: evidence for repeated re evolution of lost digits and long term persistence of intermediate body forms. Evolution: International Journal of Organic Evolution 62(8): 2042-2064.

Burbrink FT, Crother BI (2011) Evolution and Taxonomy of Snakes. In: Aldridge RD, Sever DM (eds) Reproductive Biology and Phylogeny of Snakes. Crc Press Boca Raton, FI, pp. 19-53.

Burghardt GM, Murphy JB, Chiszar D, Hutchins M (2009) Combating ophiophobia: origins, treatment, education, and conservation tools. In: Mullin SJ, Seigel RA (eds) Snakes: ecology and conservation. Comstock Publishing Associates, A Division of Cornell University Press, New York and London, pp. 262-280.

Caldwell MW (2003) "Without a leg to stand on": on the evolution and development of axial elongation and limblessness in tetrapods. Canadian Journal of Earth Sciences 40(4): 573-588.

Caldwell MW, Nydam RL, Palci A, Apesteguía S (2015) The oldest known snakes from the Middle Jurassic-Lower Cretaceous provide insights on snake evolution. Nature communications 6:5996.

Casas-Andreu G (2000) Mitos, leyendas y realidades de los reptiles en México. Ciêcia Ergo Sum, Revista Científica Multidisciplinaria de Prospectiva 7(3):286-291.

Corso DL and Corso M (2006) Fadas no divã: psicanálise nas histórias infantis. Porto Alegre, Artmed.

Cosendey BN, Salomão SR (2016) Mídia e educação: Os ofídios por trás das câmeras-répteis ou monstros? Revista Eletrônica de Educação 10(3): 251-265. 
Costa-Neto EM (2000) Conhecimento e usos tradicionais de recursos faunísticos por uma comunidade afro-brasileira. Resultados preliminares. Interciencia 25(9): 423-431.

Dias MAS, Lima NB, Figueiredo-de-Andrade CA (2018) Análise do Conhecimento etnoherpetológico dos estudantes no Município de Salinas, Minas Gerais, Brasil. Acta Biomedica Brasiliensia 9(1): 36-47.

Drumond $M A$, Guimarães $A Q$, El Bizri $H R$, Giovanetti LC, Sepúlveda DG, Martins RP (2013) Life history, distribution and abundance of the giant earthworm Rhinodrilus alatus RIGHI 1971: conservation and management implications. Brazilian Journal of Biology 73(4): 699-708.

Falótico T, Verderane MP, Mendonça-Furtado O, Spagnoletti N, Ottoni EB, Visalberghi E, Izar P (2018) Food or threat? Wild capuchin monkeys (Sapajus libidinosus) as both predators and prey of snakes. Primates 59(1): 99-106.

Fernandes-Ferreira H, Cruz RL, Borges-Nojosa DM, Alves RRN (2012) Crenças associadas a serpentes no estado do Ceará, Nordeste do Brasil. Sitientibus 11(2): 153-163.

Fredrikson M, Annas P, Fischer H, Wik G (1996) Gender and age differences in the prevalence of specific fears and phobias. Behaviour research and therapy 34(1): 33-39.

Galvão EB (2011) Acidentes ofídicos por Bothrops jararaca no Estado de São Paulo: influências de variáveis biológicas. Undergraduate thesis, Universidade Estadual Paulista, Rio Claro, Brasil.

García-López R, Villegas A, Pacheco-Coronel N. Gómez-Álvarez G (2017) Traditional use and perception of snakes by the Nahuas from Cuetzalan del Progreso, Puebla, Mexico. Journal of ethnobiology and ethnomedicine 13(1): 6.

Gomes N, Silva S, Silva CF, Soares SC (2017) Beware the serpent: the advantage of ecologically-relevant stimuli in accessing visual awareness. Evolution and Human Behavior 38(2): 227-234.

Gros-Désormeaux JR, Lagabrielle E, Lesales T, Exilie I, Tupiassu L, Béchacq D (2017) Living with or Eradicating Poisonous Snakes in Densely Populated Caribbean Islands-A Socio-Ecological Challenge for the French West Indies.
Instituto Brasileiro de Geografia e Estatística (IBGE) (2019) Brasil/São Paulo/São Paulo: Panorama. Instituto Brasileiro de Geografia e Estatística, Brasília, DF. [https://cidades.ibge.gov.br/brasil/sp/saopaulo/panorama] Accessed April 19, 2019.

Isbell LA (2006) Snakes as agents of evolutionary change in primate brains. Journal of human evolution 51(1): 1-35.

Isbell LA, Etting SF (2017) Scales drive detection, attention, and memory of snakes in wild vervet monkeys (Chlorocebus pygerythrus). Primates 58(1): 121-129.

Kawai N, He H (2016) Breaking snake camouflage: Humans detect snakes more accurately than other animals under less discernible visual conditions. PloS one doi: 10.1371/journal.pone.0164342.

Kawai N, Koda H (2016) Japanese monkeys (Macaca fuscata) quickly detect snakes but not spiders: Evolutionary origins of fearrelevant animals. Journal of Comparative Psychology 130(3): 299.

Klauber LM (1972) Rattlesnakes: their habits, life histories, and influence on mankind. 1 ed. Univiversity of California Press.

Landová E, Bakhshaliyeva N, Janovcová M. Peléšková Š, Suleymanova M, Polák J, Guliev A, Frynta D (2018) Association between fear and beauty evaluation of snakes: cross-cultural findings. Frontiers in psychology doi: 10.3389/fpsyg.2018.00333.

Lillywhite HB (2014) How snakes work: structure, function and behavior of the world's snakes. Oxford University Press.

Lima BS, Souza MM, Souto NL, Barros AB (2018) Investigando o conhecimento etnoherpetológico dos cafeicultores sobre as serpentes do município de inconfidentes, Minas Gerais. Ethnoscientia doi: 22276/ethnoscientia.v3i0.137.

LoBue V, DeLoache JS (2008) Detecting the snake in the grass: Attention to fear-relevant stimuli by adults and young children. Psychological science 19(3): 284-289.

LoBue V, DeLoache JS (2011) What's so special about slithering serpents? Children and adults rapidly detect snakes based on their simple features. Visual Cognition 19(1): 129-143. 
Marques JGW, Guerreir W (2007) Répteis em uma Feira Nordestina (Feira de Santana, Bahia). Contextualização Progressiva e Análise Conexivo-Tipológica. Sitientibus Série Ciências Biológicas 7(3): 289-295.

Marques OAV, Eterovic A, Sazima I (2019) Serpentes da Mata Atlântica: guia ilustrado para as florestas costeias do Brasil. 2 ed., Ponto A, Cotia, SP, Brazil.

Mateus MB, Pinto LCL, Moura MRD, Pires MRS (2011) A cobra-de-duas-cabeças na percepção dos moradores do povoado de Itatiaia, Minas Gerais. Biotemas 24(3):111-117.

Mello-Théry NA (2011) Conservação de áreas naturais em São Paulo. Estudos avançados 25(71): 175-188.

Mendonça LET, Vieira WLS, Alves RRN (2014) Caatinga Ethnoherpetology: relationships between herpetofauna and people in a semiarid region. Amphibian and Reptile Conservation 8(1): 24-32

Mitchell JC (1982) Snake Lore: Fact or Fiction. Virginia Wildlife 43(5): 14-15.

Moura MR, Costa HC, Avelar São-Pedro V, Fernandes VD, Feio RN (2010) O relacionamento entre pessoas e serpentes no leste de Minas Gerais, sudeste do Brasil. Biota Neotropica 10(4): 133-141.

Murphy JC, Henderson RW (1997) Tales of giant snakes: a historical natural history of anacondas and pythons. Malabar, FL: Krieger Publishing Company.

Nolan JM, Jones KE, McDougal KW, McFarlin MJ, Ward MK (2006) The lovable, the loathsome, and the liminal: emotionality in ethnozoological cognition. Journal of Ethnobiology 26(1): 126-139.

Nonga HE, Haruna A (2015) Assessment of human-snake interaction and its outcomes in Monduli District, northern Tanzania. Tanzania Journal of Health Research 17(1).

Öhman A, Mineka S (2003) The malicious serpent: Snakes as a prototypical stimulus for an evolved module of fear. Current directions in psychological science 12(1): 5-9.

Öhman A, Soares SC, Juth P, Lindström B, Esteves $F$ (2012) Evolutionary derived modulations of attention to two common fear stimuli: Serpents and hostile humans. Journal of Cognitive Psychology 24(1): 17-32.
Pandey DP, Pandey GS, Devkota K, Goode M (2016) Public perceptions of snakes and snakebite management: implications for conservation and human health in southern Nepal. Journal of ethnobiology and ethnomedicine doi: 10.1186/S13002-016-0092-0.

Penkunas MJ, Coss RG (2013) Rapid detection of visually provocative animals by preschool children and adults. Journal of Experimental Child Psychology 114(4): 522-536.

Pinheiro LT, Rodrigues JFM, Borges-Nojosa DM (2016) Formal education, previous interaction and perception influence the attitudes of people toward the conservation of snakes in a large urban center of northeastern Brazil. Journal of ethnobiology and ethnomedicine doi: 10.1186/s13002-016-0096-9.

Pinto LCL, Mateus MB, Pires MRS (2012) Conhecimentos e usos da fauna terrestre por moradores rurais da Serra do Ouro Branco, Minas Gerais, Brasil. Interciencia 37(7): 520527.

Polák J, Sedláčková K, Nácar D, Landová E, Frynta D (2016) Fear the serpent: A psychometric study of snake phobia. Psychiatry research 242: 163-168.

Pontes BES, Almeida Simões CRM, Vieira GHC, Abílio FJP (2017) Serpentes no Contexto da Educação Básica: Sensibilização Ambiental em uma Escola Pública da Paraíba. Experiências em Ensino De Ciências 12(7): 7999.

Prokop P, Özel M, Uşak M (2009) CrossCultural Comparison of Student Attitudes Toward Snakes. Society and Animals 17(3): 224-240.

Prokop P (2016) Universal Human Fears. In: Shackelford TL, Weekes-Shackelford, VA (eds) Encyclopedia of Evolutionary Psychological Science. Springer International Publishin, New York, pp. 1-5

Raimundo S (2006) A paisagem natural remanescente na região metropolitana de São Paulo. São Paulo em Perspectiva 20(2): 1931.

Santos-Fita DS, Costa-Neto EM, Schiavetti A (2010) 'Offensive'snakes: cultural beliefs and practices related to snakebites in a Brazilian rural settlement. Journal of ethnobiology and ethnomedicine doi: 10.1186/1746-4269-6-13. 
Scanlon JD, Lee MS (2011) The major clades of living snakes: Morphological evolution, molecular phylogeny, and divergence dates. In: Aldridge RD, Sever DM (eds) Reproductive biology and phylogeny of snakes. Boca Raton, FL: CRC Press, pp. 55-95.

Fundação Sistema Estadual de Análise de Dados (SEADE) (2019) São Paulo 465 Anos. Fundação Sistema Estadual de Análise de Dados, São Paulo, SP.

[http://www.seade.gov.br/wpcontent/uploads/2019/01/Municipio_Sao_Paulo.p df] Accessed on April 29, 2019.

Shibasaki M, Kawai N (2009) Rapid detection of snakes by Japanese monkeys (Macaca fuscata): an evolutionarily predisposed visual system. Journal of Comparative Psychology 123(2): 131.

Shine R (1991) Australian Snakes: A Natural History. Cornell University Press, Ithaca.

Shine R, Koenig J (2001) Snakes in the Garden: An Analysis of Reptiles "Rescued" by Community-Based Wildlife Carers. Biological Conservation 102: 271-283.

Soares SC, Lindström B, Esteves F, Öhman A (2014) The hidden snake in the grass: superior detection of snakes in challenging attentional conditions. PLoS one doi: 10.1371/journal.pone.0114724.

Somaweera R, Somaweera N (2010) Serpents in jars: the snake wine industry in Vietnam. Journal of Threatened Taxa 1251-1260.
Thrasher C, LoBue V (2016) Do infants find snakes aversive? Infants' physiological responses to "fear-relevant" stimuli. Journal of experimental child psychology 142: 382-390.

Vasconcelos-Neto LB, Garcia-da-Silva AS, Brito IAS, Chalkidis HM (2018) O Conhecimento Tradicional sobre as Serpentes em uma Comunidade Ribeirinha no Centro-Leste da Amazônia. Ethnoscientia 3: 1-7.

Vizotto LD (2003) Serpentes: Lendas, Mitos, Superstições e Crendices. Plêiade, São Paulo.

Wiens JJ, Slingluff JL (2001) How lizards turn into snakes: a phylogenetic analysis of body form evolution in anguid lizards. Evolution 55(11): 2303-2318.

Wiens JJ, Brandley MC, Reeder TW (2006) Why does a trait evolve multiple times within a clade? Repeated evolution of snakeline body form in squamate reptiles. Evolution 60(1): 123-141.

Wilke A, Mata R (2012) Cognitive Bias. In: Ramachandra VS (ed) Encyclopedia of Human Behavior. Academic Press, London, pp. 531-535.

Wilkinson M, San Mauro D, Sherratt E, Gower DJ (2011) A nine-family classification of caecilians (Amphibia: Gymnophiona). Zootaxa 2874: 41-64.

Whitaker PB, Shine R (2000) Sources of mortality of large elapid snakes in an agricultural landscape. Journal of Herpetology 121-128.
Received: 21 October 2019

Accepted: 11 June 2020

Published: 15 June 2020 